\title{
A Risk Management Analysis of Real Estate Loan Market in China
}

\author{
Mao-Hai HUANG ${ }^{1, a}$, Liu-Qing YANG ${ }^{1, b, *}$ \\ ${ }^{1}$ Fujian Jiangxia University, Fuzhou, Fujian, China \\ a314523817@qq.com, b904302918@qq.com \\ ${ }^{*}$ Corresponding author
}

Keywords: Real estate loan, Credit risk, Credit risk management.

\begin{abstract}
Since 2007 Chinese real estate market has been booming with soaring housing prices and overwhelming demands for real estate loans from developers. Chinese real estate loan market expands rapidly to meet the demands, which results in an increasing burden on commercial banks to manage real estate loan credit risk. This article looks into real estate loan market in China to present the aspects of real estate market growth, commercial banks' role in real estate loan market, and PBOC interest rate analysis. With government policy regulating the mortgage loans as guidelines, the article will analyze the risks inherent in the real estate loan market as well as the causes of such risks, and go on to propose possible policy changes for the government and commercial banks to mitigate them.
\end{abstract}

\section{Introduction}

Since 2007, China has been carrying out policies to loosen up controls of financial markets to encourage competitions. As a result, the rapid growth of financial markets aptly meets the demand of fast expanding real estate industry in China. Government opens up financial markets to various financial entities to increase competition among commercial banks, which drives the interest rate lower. The lowered interest rate, in turn, coupled with lighter government regulation becomes the main reason behind the rapid growth of the real estate loan market in China. This growth of real estate loan market results in a higher ratio of real estate loans among total loans provided by commercial banks and hence increased credit risk of these loans. It becomes crucial for the commercial banks to carefully manage the credit risk of the real estate loans. While the government can implement policy tools to provide market guidance, manage to lead the real estate market on to the safe path of growth, and achieve reasonable housing prices; commercial banks will have to emphasize on management of the real estate loan credit risks by both lowering their own credit risks in general and increasing credit requirement of mortgage loans to ensure the safe return of capitals and the generation of profits.

\section{The Current State of the Mortgage Loan Market in China}

\section{The Crucial Role of the Real Estate Market in Chinese Economy}

Real restate market is one of the most important drivers of the growth of Chinese economy. The growth of real estate industry is crucial to our GDP growth and affects all the other industries. The unique features of real estate industry make it an indispensable force to drive our GDP growth. With the fast paces of the urbanization of China, real estate developers are increasingly expanding the market into smaller cities and counties. Real estate market's expansion into rural areas can better the housing conditions of the people there, as well as increase consumptions that bring about production and trade of goods and services. So it is obvious for us to see that the real estate industry is a key one to improve the life of Chinese people not only in terms of housing conditions but also in terms of economic growth in general. 


\section{The State Of The Real Estate Loan Growth}

Analysis Of Real Estate Development And Sale Statistics. From following data, the government has been effectively reining in the overheated real estate market since we can see that the residential real estate sale has been declining since 2009. Although the market is still growing with increasing investment, the 2012 level of 71.8 trillion was $16.2 \%$ increment from the year before, which is $11.7 \%$ lower than the $27.9 \%$ of increment from the year before; in 2012 the total space sold were 111.3 billion square meters, an increment of $1.8 \%$, which is $3.10 \%$ lower than the $4.9 \%$ increment of 2011 from the year before. In the mean time, in 2012 the newly acquired space and space under construction declined from the year before. So it is obvious that with increasing demand, the real estate industry is still growing although it is now becoming a buyers' market rather than sellers' market like before. In 2012 the real estate market experienced a slow recovery with increasing pressure on prices in some areas. It reveals the conflicting roles of government to rein in speculation and to increase investment at the same time. It also shows that credit risk becomes the key issue in the real estate loan market.

Table 1 2008-2012 Real Estate Development And Sale Figures

\begin{tabular}{|c|c|c|c|c|c|c|}
\hline \multicolumn{2}{|l|}{ Year } & \multirow{2}{*}{$\begin{array}{l}2008 \\
\text { Figure }\end{array}$} & \multirow{2}{*}{$\begin{array}{l}2009 \\
\text { Figure }\end{array}$} & \multirow{2}{*}{$\begin{array}{l}2010 \\
\text { Figure }\end{array}$} & \multirow{2}{*}{$\begin{array}{l}2011 \\
\text { Figure }\end{array}$} & \multirow{2}{*}{\begin{tabular}{|l|}
2012 \\
Figure
\end{tabular}} \\
\hline Index & Unit & & & & & \\
\hline 1. Investment total & $\begin{array}{ll}100 & \text { million } \\
\text { Yuan } & \end{array}$ & 30580 & 36232 & 48267 & 61740 & 71804 \\
\hline Residential & $\begin{array}{l}100 \quad \text { million } \\
\text { Yuan }\end{array}$ & 22081 & 25619 & 34038 & 44308 & 49374 \\
\hline 90 square meters \&smaller & $\begin{array}{l}100 \quad \text { million } \\
\text { Yuan }\end{array}$ & 6416 & 8351 & 10665 & 13637 & 16789 \\
\hline 2. Total construction space & $10,000 \mathrm{~m}^{2}$ & 274149 & 319650 & 405539 & 507959 & 573418 \\
\hline Residential & $10,000 \mathrm{~m}^{2}$ & 216671 & 250804 & 314943 & 388439 & 428964 \\
\hline $\begin{array}{l}\text { 3. Newly constructed } \\
\text { space }\end{array}$ & $10,000 \mathrm{~m}^{2}$ & 97574 & 115385 & 163777 & 190083 & 177334 \\
\hline Residential & $10,000 \mathrm{~m}^{2}$ & 79889 & 92463 & 129468 & 146035 & 130695 \\
\hline $\begin{array}{l}\text { 4. Completed construction } \\
\text { space }\end{array}$ & $10,000 \mathrm{~m}^{2}$ & 58502 & 70219 & 75961 & 89244 & 99425 \\
\hline Residential & $10,000 \mathrm{~m}^{2}$ & 47750 & 57694 & 61216 & 71692 & 79043 \\
\hline 5.Commercial real estate & $10,000 \mathrm{~m}^{2}$ & 62089 & 93713 & 104349 & 109946 & 111304 \\
\hline Residential & $10,000 \mathrm{~m}^{2}$ & 55886 & 85294 & 93052 & 97030 & 98468 \\
\hline 6. Total investment & $\begin{array}{l}100 \quad \text { million } \\
\text { Yuan }\end{array}$ & 38146 & 57128 & 72494 & 83246 & 96538 \\
\hline Domestic loans & $\begin{array}{l}100 \quad \text { million } \\
\text { Yuan }\end{array}$ & 7257 & 11293 & 12540 & 12564 & 14778 \\
\hline Mortgage loans & $\begin{array}{l}100 \quad \text { million } \\
\text { Yuan }\end{array}$ & 3573 & 8403 & 9211 & 8360 & 10524 \\
\hline 7. Yearly developed space & $10,000 \mathrm{~m}^{2}$ & 36785 & 31906 & 40970 & 40973 & 35667 \\
\hline
\end{tabular}


Table 2 2008-2012 Real Estate Development And Sale Figures Increase In Percentage

\begin{tabular}{|c|c|c|c|c|c|c|}
\hline \multicolumn{2}{|c|}{ Year } & 2008 & 2009 & 2010 & 2011 & 2012 \\
\hline Index & Unit & $\begin{array}{c}\text { increase } \\
\text { from last } \\
\text { year\% }\end{array}$ & $\begin{array}{c}\text { increase } \\
\text { from last } \\
\text { year\% }\end{array}$ & $\begin{array}{c}\text { increase from } \\
\text { last year\% }\end{array}$ & $\begin{array}{c}\text { increase from } \\
\text { last year\% }\end{array}$ & $\begin{array}{l}\text { increase from } \\
\text { last year\% }\end{array}$ \\
\hline $\begin{array}{c}\text { 1. Investment } \\
\text { total }\end{array}$ & $\begin{array}{l}100 \\
\text { million } \\
\text { Yuan }\end{array}$ & $20.90 \%$ & $16.10 \%$ & $33.20 \%$ & $27.90 \%$ & $16.20 \%$ \\
\hline Residential & $\begin{array}{l}100 \\
\text { million } \\
\text { Yuan }\end{array}$ & $22.60 \%$ & $14.20 \%$ & $32.90 \%$ & $30.20 \%$ & $11.40 \%$ \\
\hline $90 \mathrm{~m}^{2} \&$ smaller & $\begin{array}{l}100 \\
\text { million } \\
\text { Yuan }\end{array}$ & $50.70 \%$ & $24.10 \%$ & $27.40 \%$ & $28.00 \%$ & $21.90 \%$ \\
\hline $\begin{array}{l}\text { 2. Total } \\
\text { construction } \\
\text { space }\end{array}$ & $\begin{array}{c}10,000 \\
\mathrm{~m}^{2}\end{array}$ & $16.00 \%$ & $12.80 \%$ & $26.60 \%$ & $25.30 \%$ & $13.20 \%$ \\
\hline Residential & $\begin{array}{c}10,000 \\
\mathrm{~m}^{2}\end{array}$ & $16.00 \%$ & $12.50 \%$ & $25.30 \%$ & $23.40 \%$ & $10.60 \%$ \\
\hline $\begin{array}{l}\text { 3. Newly } \\
\text { constructed } \\
\text { space }\end{array}$ & $\begin{array}{c}10,000 \\
\mathrm{~m}^{2}\end{array}$ & $2.30 \%$ & $12.50 \%$ & $40.70 \%$ & $16.20 \%$ & $-7.30 \%$ \\
\hline Residential & $\begin{array}{c}10,000 \\
\mathrm{~m}^{2}\end{array}$ & $1.40 \%$ & $10.50 \%$ & $38.80 \%$ & $12.90 \%$ & $-11.20 \%$ \\
\hline $\begin{array}{l}\text { 4. Completed } \\
\text { construction } \\
\text { space }\end{array}$ & $\begin{array}{c}10,000 \\
\mathrm{~m}^{2}\end{array}$ & $-3.50 \%$ & $5.50 \%$ & $4.50 \%$ & $13.30 \%$ & $7.30 \%$ \\
\hline Residential & $\begin{array}{c}10,000 \\
\mathrm{~m}^{2}\end{array}$ & $-4.20 \%$ & $6.20 \%$ & $2.70 \%$ & $13.00 \%$ & $6.40 \%$ \\
\hline $\begin{array}{c}\text { 5.Commercial } \\
\text { real estate }\end{array}$ & $\begin{array}{c}10,000 \\
\mathrm{~m}^{2}\end{array}$ & $-19.70 \%$ & $42.10 \%$ & $10.10 \%$ & $4.90 \%$ & $1.80 \%$ \\
\hline Residential & $\begin{array}{c}10,000 \\
\mathrm{~m}^{2}\end{array}$ & $-20.30 \%$ & $43.90 \%$ & $8.00 \%$ & $43.90 \%$ & $2.00 \%$ \\
\hline $\begin{array}{l}\text { 6. Total } \\
\text { investment }\end{array}$ & $\begin{array}{l}100 \\
\text { million } \\
\text { Yuan }\end{array}$ & $1.80 \%$ & $44.20 \%$ & $25.40 \%$ & $44.20 \%$ & $12.70 \%$ \\
\hline Domestic loans & $\begin{array}{l}100 \\
\text { million } \\
\text { Yuan }\end{array}$ & $3.40 \%$ & $48.50 \%$ & $10.30 \%$ & $0.00 \%$ & $13.20 \%$ \\
\hline Mortgage loans & $\begin{array}{l}100 \\
\text { million } \\
\text { Yuan }\end{array}$ & $-29.70 \%$ & $116.20 \%$ & $7.60 \%$ & $-12.20 \%$ & $21.30 \%$ \\
\hline $\begin{array}{l}\text { 7. Yearly } \\
\text { developed } \\
\text { space }\end{array}$ & $\begin{array}{c}10,000 \\
\mathrm{~m}^{2}\end{array}$ & $-8.60 \%$ & $-18.90 \%$ & $28.40 \%$ & $2.60 \%$ & $-19.50 \%$ \\
\hline
\end{tabular}

The Ratio Of The Real Estate Loans Of The Total Loans By Commercial Banks. In the example of Bank of China, from 2007 to 2011, the percentage of real estate loan balance vs. total loan balance was getting smaller as per the chart below.

From Table 3 we can see that between 2007 and 2011, BOC was increasing the total loans balance. The level of real estate loan balance and total loan balance both got much higher with the ratio of the real estate loan to total loan decreasing from $31.91 \%$ in 2007 to $17.8 \%$ in 2011 . Evidently, this is due to the government increased regulation in the real estate loan market. BOC lowered their real estate loan ratio to total loans to better manage the credit risk associated with the real estate loans. 
Table 3 BOC 2007-2011 Real Estate Loan Balance And Total Loan Balance Unit: 100 million yuan

\begin{tabular}{|l|l|l|l|}
\hline Year & Mortgage Balance & \multicolumn{1}{|c|}{ Average Loan Balance } & Ratio\% \\
\hline 2007 & 8507.60 & 26655.49 & $31.91 \%$ \\
\hline 2008 & 8640.10 & 38152.27 & $22.64 \%$ \\
\hline 2009 & 7642.46 & 30934.83 & $24.70 \%$ \\
\hline 2010 & 9712.16 & 38950.37 & $24.93 \%$ \\
\hline 2011 & 10876.87 & 60963.96 & $17.80 \%$ \\
\hline
\end{tabular}

\section{The Real Estate Loan Interest Rate Changes.}

Table 4 2007-2012 PBOC Interest Rates[3]

\begin{tabular}{|l|l|l|l|}
\hline Time Period & Interest rate\% & Time Period & Interest rate\% \\
\hline $2007-3-18$ & $7.11 \%$ & $2008-12-23$ & $5.94 \%$ \\
\hline $2007-5-19$ & $7.20 \%$ & $2010-10-20$ & $6.14 \%$ \\
\hline $2007-8-22$ & $7.56 \%$ & $2010-12-26$ & $6.40 \%$ \\
\hline $2007-12-21$ & $7.83 \%$ & $2011-2-9$ & $6.60 \%$ \\
\hline $2008-9-16$ & $7.74 \%$ & $2011-4-6$ & $6.80 \%$ \\
\hline $2008-10-9$ & $7.47 \%$ & $2011-7-7$ & $6.90 \%$ \\
\hline $2008-10-30$ & $7.20 \%$ & $2012-6-8$ & $6.80 \%$ \\
\hline $2008-11-27$ & $6.12 \%$ & $2012-7-6$ & $6.55 \%$ \\
\hline
\end{tabular}

Note: the interest rate quoted is the annual rate of commercial loans of 5 years and above

From the above chart, we can see that Chinese government adjusted interest rate level for many times since 2007 with the high of $7.83 \%$ and the low of $5.94 \%$ with a difference of $31.82 \%$. The tightening of currency policy through higher level of interest rate is aimed at preventing overheated growth of economy so as to avoid inflation stemming from rising prices; while the lowering of interest rate is to stimulate the growth of economy as a policy choice in time of crisis, which to some extent is beneficial for the real estate market. So the government is sending signals to the banks and real estate consumers by way of currency policy such as interest rate level adjustment to avoid market bubbles to form, steady the price level, and encourage sensible market behaviors. The real estate market will only benefit from a balanced ratio of supply and demand as well as strong risk management.

\section{The Risk Of Real Estate Loans}

The economy in China has been booming in the past 10 years. The real estate market as a result is growing quickly. A side effect of the growth of real estate market is the rapid expansion of real estate loan business of state owned commercial banks, with the real estate loan balance reaching 121.1 trillion Yuan, an increase of $12.8 \%$ from year before. The credit risk of these loans is increasing when the real estate market is bubbling up. The government reacted with such regulations as "loan limit", "purchase limit", "price limit", and guaranteed ownership, which were coupled with such monetary policies like increasing interest rate and raising capital ratio of commercial banks. These policies are proven effective to rein in over-investment by local governments as well as the real estate development in general. The real estate market experienced the low level of transactions and lower pace of price increase in 2010, stronger regulations and cooler land trading in 2011, and the upward spiral of growth in real estate market and the resurgence of real estate loan market in 2012. We were 
experiencing an improvement in capital source as well as higher demands in real estate market. The credit risk of real estate loans is on the rise.

\section{Risk Management Analysis of Current Real Estate Loan Market in China}

\section{The Origin Of The Real Estate Loan Market Risk}

Policy Shifting Caused Systemic Risk. As an important pillar of China's economy, real estate industry enables a wide range of other industries and currently is developing with a strong pace. However, the government's macroeconomic adjustment policy is not formulated organically from market reaction, and may cause high volatility on the market. If government regulations on the land use right, investment scale, investment direction, rental and sale price are tightened, it will cause shift on government tax policy and fiscal policy. These government policy shifting can strongly influence the real estate market, and cause systemic risk.

Real Estate Bubble Accumulation Risk. Although the development of economically affordable housing and low-rent housing suppresses the overheated real estate market in China to some degree, the scale of these social housing only takes up a small percentage of the overall residential housing development. The large imbalance between supply and demand heightens the shortage of both residential housing and economically affordable housing in some cities. The overheated real estate market is quickly accumulating risk, causing severe structural housing bubble. The key symptoms of housing bubble include following. First, some of the residential housing investors are turning into speculators. Second, the total amount and ratio of vacant residential buildings are too high. Third, the rise of housing price deviates from the law of value. Fourth, there is a serious shortage of real estate developers' own funds, while most developers rely on bank loans to buy lands. If the developers can no longer sell the house, their funding pipeline will break, pushing the real estate market into deep trouble. Many bank loans can quickly become bad debts. Unfortunately, the value of mortgage loan equity for most commercial banks is evaluated based on the market price; therefore, the real estate loan based on the housing "bubble" will face a greater risk.

Hidden Risk in Personal Housing Loan. In accordance with international practice, $30 \%$ to $40 \%$ of the monthly income is used as the cordon for monthly mortgage payment. Crossing this redline will significantly increase the risk of repayment. According to the survey, home mortgage accounts for $20 \%-50 \%$ of the monthly income for nearly half of the people, and more than $50 \%$ for one third of the household. Among them, real estate mortgage for $31.8 \%$ of household has crossed the red line and become a housing loan liability [1]. Such a large contingent liabilities cannot be blamed solely on the borrower, and the major commercial banks should also share certain responsibility. Their practice not only causes high debt burden on the borrower, but also endangers the stability and security of the nation's financial system. Therefore, once the personnel housing mortgage exceeds the individual's repayment capacity, it will generate a greater risk for both the individual and the commercial banks.

Cumulative Risk Caused by the Deviation from Regulation Policy. Deviation from the regulation policy can lead to accumulative risk in real estate industry. For example, from 2008 to 2010 the Chinese government adopted the 4 trillion economic stimulus plan specifically designed for the real estate market. The policy ignited the market and pushed the housing price to a new high. Real estate industry and related interest groups gained high profits through the rising housing prices. Therefore, price regulation of China's real estate market is absolute and long-term. The consumer housing loans from commercial banks will slow down as the nation's macro-control on real estate market evolves deeper. In addition, proper mortgage management is not in placed, coupled with several other factors, resulting in a substantial amount of real estate non-performing assets, which further increase the credit risk faced by the banking sector.

\section{Bank’ Own Reasons}

Inherent Instability of Bank's Real Estate Credit Business. For a long time, funding sources of China's real estate development enterprises are mainly domestic commercial bank loans. Real estate 
business's own financing makes up of a lower proportion, while the bank credit funds are of higher proportion. Among the existing real estate companies financing channels, the bank loan risks and costs are the lowest. With the development of China's real estate market, the scale of commercial banks real estate credit continues to expand, and real estate financing source remain largely from banks. The situation of high dependence on bank loans has not fundamentally changed. However, with the adjustment of China's macroeconomic policy, the bank will face liquidity, credit policy and a series of policy changes, which has its inherent instability.

The Lack of Investment and Financing Channels in Financial System. China's real estate industry is going through a rapid development period, but the associated financial industry is relatively lagging behind, causing a series of financial risks and hazards. At present stage, the sources for real estate financing are limited, and the real estate risks are accumulated on the bank. However, the low interest rate or even negative interest rate push many residents to invest their money into the residential and commercial real estate properties, resulting in an increase in real estate investment buyers. In particular, the speculative real estate investment in some region further increases the risk of real estate consumer loans. Due to the relatively high threshold of equity financing, at present time there are only a handful of real estate development funds in China capable of direct real estate financing. Direct financing is only a small proportion of real estate financing. For example, there are only 85 companies whose main business are in real estate development in China's A-share market, which accounts for $6.3 \%$ of the total A -share listed companies, and $0.28 \%$ of the total number of real estate enterprises. The total market capital of listed real estate companies is more than 1700 billion yuan, with market capitalization of over 600 billion. The market capitalization is of less than $10 \%$ of the annual real estate investment, and the debt financing is of even lower proportion. Real estate development companies has so far been unable to form a sufficient scale in the bond market, currently less than $0.01 \%$ and the corporate bonds balance of only 200 million yuan[2].

\section{Countermeasures and Solutions to China's Real Estate Consumer Credit Risk Control}

\section{Government's Countermeasures and Solutions to Real Estate Credit Risk Control}

Adjustment of Land Supply Plan. China's current land supply plan does not separate various types of land development supply. In most places three quarters of new construction sites are for the industrial development, thus compressing the demand for residential development land. Therefore, a separate plan for new housing development should be considered when developing land supply plan. Meanwhile, residential housing land supply plan should be developed based on the rational planning of the stock of housing and the development of energy-saving residences, and form housing construction and consumption patterns which are in line with China's national conditions.

Levy Property Tax As Soon As Possible. Levying property tax can not only increase the cost of housing, but also ease the pressure on the housing market. It will change home buyers's expectations for the future, and also inhibit the advance of consumption, thus controlling the housing price within reasonable limit. Property tax will also provide new revenue growth for the government and ignite government's enthusiasm, thus facilitating the implementation of macro-control policies. Meanwhile, we should strengthen the collection of Land Appreciation Tax (LAT), and curb speculative demand for housing. Considering the current difficulties in the actual collection of LAT, LAT can be integrated into government tax or other taxes levied in the long run. This solution will not only facilitate the collection of LAT, but also contribute to combating speculation.

Strengthen the Housing Demand Management. First, differentiated housing market management needs to be imposed. The housing supply should be increased in order to encourage rigid demand; home buying should be restricted in order to combat ahead of demand and speculative demand. Secondly, the management of rental housing needs to be strengthened. The government should improve the management rules and regulations for rental housing market, construct healthy housing rental system, and foster rational housing consumption concept. Third, the government should guide the development of the real estate market by strengthening rational consumption 
concept, advocating the building of multiple family housing, and guiding the development of second-hand housing market and rental housing market, etc., so that supply and demand in the real estate industry are kept in a relatively balanced state. Fourth, the government must strengthen the supervision of the real estate market, and deal severe blow to speculative demand in order to avoid a lot of idle capital inflows, thus guiding the direction of the rationalization of the real estate market.

Strengthen Financial Monitoring Efforts. First, we should strengthen the supervision of commercial banks' funds. In order to curb speculative demand and reduce credit risk, banks need to strengthen the real estate consumer credit risk management, control the proportion of real estate housing loans credit, and impose strict restrictions on real estate development loans. In addition, banks should audit individual's qualifications for housing mortgage, and strictly limit the loan approval for multiple-home buyers. Secondly, banks should strengthen the monitoring of foreign investment. In order to promote the development of the real estate market and prevent banking financial risks, commercial banks should pay special attention to traffic and the flow of foreign investment and scientifically assess the real estate consumer credit risk.

Development of Diversified Real Estate Finance Market. China should develop a diversified real estate finance market and form a market system coexisted by a variety of financial assets and financial instruments in order to diversify credit risks. Over-reliance of real estate industry on bank financing is not only unbeneficial to its development, but also a violation to commercial banks' liquidity and safety principles. A developed securitization market should exist within the real estate finance markets. In this market, there are various real estate financial instruments, including investment funds, trust securities, and indexed securities. Securitization of real estate can promote real estate professional management, and achieve a reasonable distribution of resources.

\section{Commercial Banks' Control Policies and Measures Toward the Real Estate Consumer Credit Risk}

Strengthen Mortgage Credit Risk Management. Most of China's current land acquisition and real estate development funds are derived from the bank credit funds, which increases investment risk for the banks and real estate investors. With the increase in real estate development projects, real estate credit accounts for a growing proportion of total financial system, and real estate development loans have become important commercial bank credit operations. How to prevent and control the real estate consumer credit risk is currently an urgent problem. Therefore, we should strictly control the individual mortgage approval, control the size and number of personal real estate, improve collateral evaluation system, and strengthen the mortgage consumer credit risk management.

Innovative and Diversified Financing Products. From the experience of developed countries whose real estate markets are mature, their real estate financing products show diversity, including real estate investment funds, real estate investment trusts and other varieties. China's real estate financing products design should proceed from China's reality. Within the risk tolerance of the majority of the people, we should consider developing real estate trust, real estate investment trusts (REITs), and other real estate financing products following the investment guideline of first-hedge-then-profitable.

Improving the Risk Prevention Capability of Commercial Banks. Commercial banks should strengthen their risk management and improve their level of risk prevention. First, loan officers must establish a good work ethic and sense of risk, earnestly review the loan prior to the survey, timely track clients' fund usage and project development progress, in order to ensure timely repayment of the loan. Second, we should establish a set of comprehensive analytical and statistical research system in order to strengthen the analysis and forecasting of real estate market and customers. We should also improve real estate credit risk early warning capability. Finally, we should strengthen the training of loan officers, and improve their business professional level and their ability to judge the market. We should ensure that the credit system is running smoothly from every aspect, and avoid risks in a timely manner. 


\section{Conclusion}

In summary, the real estate consumer credit concerns each and every family. Real estate consumer credit risk is influenced by the real estate market, which in turn affects the development of the real estate market. In addition, it is also affected by government policy and the country's overall economic development. Thus, the government must guide the development of the real estate market, so that it can sustain healthy and stable development. The commercial banks should establish and improve the risk prevention system for consumer real estate credit business as soon as possible, establish a comprehensive risk control mechanism, and ensure the safety of the loan to the maximum extend, in order to promote a healthy development of the real estate consumer credit business, and Enhance the overall anti-risk ability of commercial banks.

\section{References}

[1] Fei Mao, "Fangnu's" risk is also bank's risk [N], Jiangxi Daily, 2006-04-18, (2).

[2] Xuefei Zhou, The real estate financing and commercial bank credit business innovation [J], China Real Estate Finance, 2007, 4:7-11.

[3] People's Bank of China, 2012 financial institutions loan investment statistical report [R] Beijing: People's Bank of China, 2013-01-24.

[4] Graduate School of Chinese Academy of Science, Real Estate Development Strategy Research Group, 2009 China Real Estate Market Review and Outlook [M]. Beijing: Science Press, 2009:10-11.

[5] Caiqin Geng, Mortgage is the main liability of residents [N]. Beijing Daily, 2006-04-26, (112).

[6] Ruifeng Niu, Jingguo Li, Real Estate Analysis and Forecast for 2004 2005 [M].Beijing: Social Sciences Academic Press, 2005:1-10.

[7] Shi Yi, Review of status of the real estate (part one) the real estate in the economy [N]. China Real Estate News, 2012-08-02, (2).

[8] Lilei Tu, 2012 Annual Real Estate Outlook [R]. Shanghai: Haitong Securities Institute, 2013-03-01. 